\title{
SOME NEW OPIAL DYNAMIC INEQUALITIES WITH WEIGHTED FUNCTIONS ON TIME SCALES
}

\author{
S. H. Saker, M. M. Osman, D. O’Regan And R. P. Agarwal
}

Abstract. In this paper we prove some new dynamic inequalities with two weight functions and some new dynamic inequalities with two unknown functions of Opial type on time scales. The main results will be proved by employing Hölder's inequality, the chain rule and some basic algebraic inequalities.

Mathematics subject classification (2010): 26A15, 26D10, 26D15, 39A13, 34A40.

Keywords and phrases: Opial's inequality, time scales, Hölder's inequality.

\section{REFERENCES}

[1] M. Bohner And B. Kaymakçalan, Opial Inequalities on time scales, Annales Polonici Mathematici, vol. 77, no. 1, pp. 11-20, 2001.

[2] M. Bohner And A. Peterson, Dynamic Equations on Time Scales: An Introduction with Applications, Birkhäuser, Boston, 2001.

[3] M. Bohner And A. Peterson, Advances in Dynamic Equations on Time Scales, Birkhäuser, Boston, 2003.

[4] S. Hilger, Analysis on measure chains - a unified approach to continuous and discrete calculus, Results Math. 18 (1990) $18-56$.

[5] V. KaC And P. Cheung, Quantum Calculus, Springer, New York, 2001.

[6] B. KARPUZ, B. KAYMAKÇALAN, AND Ö. ÖCLAN, A generalization of Opial's inequality and applications to second order dynamic equations, Differential Equations and Dynamical Systems, vol. 18, no. 1-2, pp. 11-18, 2010.

[7] C. T. Lin, AND G. S. YANG, On some integrodifferential inequalities, Tamkang Journal of Mathematics, vol. 16, pp. 123-129, 1985.

[8] B. G. PachPatTe, On Opial-type integral inequalities, Journal of Mathematical Analysis and Applications, vol. 120, pp. 547-556, 1986.

[9] S. H. SAKER, Some Opial-type inequalities on time scales, Abstract and Applied Analysis, vol. 2011, Article ID 265316, 19 pages, 2011.

[10] H. M. Srivastava, K. L. Tseng, S. J. Tseng, and J. C. Lo, Some weighted Opial-type inequalities on time scale, Taiwanese Journal of Mathematics, vol. 14, no. 1, pp. 107-122, 2010.

[11] F. H. Wong, W. C. Lian, S. L. Yu, And C. C. YeH, Some generalizations of Opial's inequalities on time scales, Taiwanese Journal of Mathematics, vol. 12, no. 2, pp. 463-471, 2008. 